If not worthy of presentation to any herbarium, would any competent botanist classify it for the sake of the duplicates? F. G. S. P.

\section{General Travelling Notes}

DURING the years 1857-66 I was in India, and in that period travelled much, both in the Plains and the interior of the Himalaya.

Since my return to England I have constantly regretted that I took few notes, and those few notes, from lack of knowledge, of little or no value, on flora, fauna, geology, and altitudes. In a few months I shall return to the same part of India (North West Provinces and Punjâb), and purpose re. maining in that country for some years. There are many men in the army who, like myself, have a general taste for scientific observations, but our efforts end in gratifying our own minds only, our observations lacking sufficient accuracy and classification, whilst much is overlooked from sheer ignorance as to the how and where to look.

To the end that I (and others of like mind) may, perchance, furnish some useful jotings during my next term of foreign service, can any contributor to NATURE inform me where the following are to be met with :-

I. A plain code of what to look for and observe, after the manner of, but shorter than, "The Scientific Orders of the Challenger," published in NATURE for Jan. 9 and 30.

2. What is the best text-book on each head (e.g. on barometrical and thermometrical observations, Indian geology, botany, \&c.). It is very essential each such text-book should be comprised in one handy volume; if possible as clear and concise as Tyndall's "Lectures on Electricity."

3. What instruments should be taken. I suggest-An ordinary thermometer, tested at Kew ; a max. and a min thermometer; an aneroid (of what size?); a prismatic compass; an Abney's clinometer-level for ascertaining the slope and consequent height of mountains and depths of valleys roughly; also a small portable rain-gauge, if such is made; a simple microscope, and a magnifying glass. Are these sufficient? and if so, where should they be procured, and at what price? the cost being a vital point.

4. Can these, or similar instruments, be obtained in a single case sufficiently small to be carried, like a smali theodolite box in one haind?

F. G. S. P.

\section{Mirage}

THE following references to the literature of this subject are in answer to the note by Prof. J.D. Everett in NATURE for January 2 last :--

Bravais, Aug. - “ Notice sur le mirage," Annuaire Soc. Meteor. Fr., p. 227 (1852), p. 55 (1855).

Dufour, Chailes. - "Mirages et réfractions aunormales sur le lac Leman," Bull. Soc. Vaud. Lausanne, vol. iv. p. 366 (1854-5) 386 ; vol. v. p. $26(1856) ; 217$.

Escayrac de Lauture.-."Sur le ragle ou hallucination du désert," Bull. Soc. Geogr, vol. ix. p. I2I (1855).

Gergonne, J. D.--" Recherclies sur les refractions terrestres et particulièrement sur le mirag -," Notice T'rao. Acad. Gard., p. I29 ( 1808 )

Gergonne, J. D.-- "Essai analytique sur la phenomène du mirage," Ann. Math. Gergonne, xx. p. I (1829).

Giovene, G. M. - "Wunderbare Phänomene nach Art der Fata Morgana," Gilbert, Annal. xii. p. I (1803).

Jackson, C. T.- " Observations on the Mirage seen on Lake Superior in July and August 1847," Proc. Amer. Assoc., p. 143 (I849).

Kelly, W.- "Ori some extraordinary forms of Mirage," Trans. Lit. Soc. Quebec, vol. iii. p. 292 (1837).

Orioli, F._."Delia Fata Morgana," Tortolini Annali, ii. p. 47 (1851).

Parés.- "Note sur le Mirage," Comptes Rendus, vol. xii. p. 87 (1855).

Parés. - "Note sur le Mirage des Côtes du departement de

l'Herault," Mem. Acad. Sci. Montpellier, iii. p. I; 493 (1855)

\section{Brilliant Meteor of Feb. 3}

To supplement Prof. Osborne Reynolds' interesting paper on the meteor of February 3, which he saw in Manchester, and which he thinks must have passed over Chester and Liverpool (NATURe, February 20, p. 315), I enclose you a cutting from a local Cheshire paper showing that this meterr was seen about the same time in Northwich, which is some twenty-five or thirty miles S.W. from Manchester, and almost in a direct line drawn from Manchester to Chester.

By consul:ing the various local papers published in Northwich, Chester, Birkenhead, Liverpool, \&c., it could easily be discovered at what place it was last seen, and where the loudest explosion was heard, and so the approximate path of this splendid meteor and its height might be traced out. These papers will mostly all be found in the Exchange and the Athenæum Reading Rooms, Manchester, where I believe they are regularly filed.

Merton College, Oxford

J. P. EARWAKER

"A Meteor Shower at Northwich.-At Northwich on Monday night, February 3, about ten o'clock, a very brilliant meteor was observed in the sky passing from east to west. The meteor displayed an intense white light in its course, and emitted sparks which appeared of various hues. It was visible about six or eight seconds, and from one to two minutes after the passage of the meteor a loud rumbling report like distant thunder was heard. The night was very clear, and starlight at the time."

A VERY bright meteor was imperfectly seen here by me at $9^{\mathrm{h}} 58^{\mathrm{m}}$ on Monday evening. February 3. At the time of its appearance the sky was much clouded though not entirely overcast, and became suddenly lluminated by what I at first considered to be flashes of lightning. The clouds in the north sky particularly were illuminated, and as I thought it possible that the phenomenon might be due to the appearance of a large fireball behind the clouds, I nuted the exact situation in which the greatest quantity of light (which was about equal to the moon when five days past conjunction) existed. Tuis was, as accurately as could posibly be determined, at a place about $10^{\circ}$ eastward of the north point, or north by eart, and in the vicinity of the horizon. When traversing this part of its parh it is possible that the meteor was at its brightesi, and on the point of disappearance. It was impos-ible tu nute any further details as to the exact cuurse of the Juminous appearance seen. inasmuch as but few stars were perce,, tible, and the north sky was much obscured by cumulus cluuds. This meteor was also seen at Manchester at $9^{\mathrm{h}} 57^{\mathrm{m}}$; it appeared near the zenith of that station.

Brisıol

WILliam F. DENNING

\section{Inherited Feeling}

As every instance of inherited antipathy in the offspring of Turk adds to the weight of proof, I beg to state that a mastiff in my possession, a grandsun of Turk, and a bruther of Mr. Brooke's dog, showed the same unaccountable antipathy to butchers, manifesting violent rage when any one of that honourable fraternity showed himself in ihe yard where he was kept. He was otherwise of a remarkably mild and gentle disposition.

Bowdon, near Manchester,

ARTHUR RANSOW Feb. 2I

WoULD it not test the correctness of Mr. Wallace's ingenious theory as to animals finding their way back over an unseen country by their sense of smell, to shut up a cat in a basket along with a piece of stale fish, the scent of which would certainly overpower any external scent by which it might be able to trace the way back? It seems to me that many instances are on record of this curious power of certain animals, especia.ly of cats, which are quite inexplicable on Mr. Wallace's hypotbesis.

ALFRED W. BENNETT

\section{External Perception in Dogs}

THE view to which $\mathrm{Mr}$. Wallace gives expression in your last number had occurred also to me, and I should like, with your leave, to offer a remark or two in support of it.

That a dog shut up in a basket may through smell acquire a series of impressions so definitely marked as to be able therewith to find its way back to the place it was taken from, becomes less improbable if we think what is the part that must be played by smell in its ordinary objective experience. Our external world (whether as actually perceived or imaginatively represented) may be called a world of sights and touches, blended with and modifying each other in the most intimate way. These mutually involved sights and touches, in our consciousness, are run out into the form of a continumn in space (how or why it is not to 